\section{In-row Spacing Influences Triploid Watermelon Yield and Crop Value}

\author{
Carl E. Motsenbocker and \\ Ramon A. Arancibia
}

Additional index words. plant spacing, plant population, seedless watermelon, Citrullus lanatus

Summary. Triploid watermelon (Citrullus lanatus), commonly called seedless watermelon, is increasing in popularity and market share. The optimum in-row spacing of triploid watermelon has not been studied previously. Triploid watermelon 'Crimson Jewel' and 'Honeyheart' were grown with drip-irrigation and black plastic mulch at 1-, 2-, 4-, 6-, and 8-ft (0.3-, 0.6-, 1.2-, 1.8-, and 2.4-m) inrow spacings in 1996 and 2-, 3-, 4-, 5-, 6-, 7-, and 8-ft. (0.6-, 0.9-, 1.2-, 1.5-, $1.8-, 2.1-$, and $2.4-\mathrm{m})$ spacings in 1997 to determine the effect of in-row plant spacing on fruit yield. Marketable yield of 'Crimson Jewel' was not affected by in-row spacing while narrower in-row spacing resulted in greater 'Honeyheart' yield both years. For both cultivars, narrower spacing resulted in the highest number of fruit per acre, but primarily more extrasmall and small fruit. Fruit number per plant, fruit weight per plant, and individual fruit weight were higher at wider spacings, and yield per acre was lower. The data suggest that triploid watermelon yield, fruit weight and number can be adjusted by in-row spacing. Narrower in-row spacing can maximize yields, depending on the specific grower's cultural practices. In wider in-row spacings, the yield of medium and large fruit is maintained with a subsequent decrease in extra small and small fruit. Gross returns per acre were only different for farmers' market prices, not wholesale, and net returns were not significantly influenced by in-row spacing.

Department of Horticulture, Louisiana State University AgCenter, Baton Rouge, LA 70803.

The authors would like to acknowledge the assistance of personnel at the Burden Research Center, Baton Rouge and Jose R. Andino.
$\mathrm{T}$ he demand for and the popularity of watermelon (Citrullus lanatus) is increasing in the United States as evidenced by the $33 \%$ increase in per capita consumption from 1980 to 1995 (USDA Economic Research Service, 1998). Triploid watermelons, commonly called seedless, are increasing in popularity and in market share; between 1992 and 1999 the number of households purchasing seedless watermelons increased 17\% (The Packer, 1999). Triploid watermelons are expected by some in the industry to constitute a large portion of the watermelon market in the future (Blank, 1999), and, in recent years, triploid watermelons accounted for at least $30 \%$ of the California watermelon acreage (Mayberry et al., 1996). Although triploid watermelon is increasing in market share, the optimum cultural practices for this watermelon type have not been investigated thoroughly. Management of production practices and minimizing costs are increasingly important. This is especially important for triploid watermelon because seeds are expensive and seedless watermelon crops are established by transplanting.

Several researchers conducted research to investigate the optimal spacing for diploid (seeded) watermelon. Researchers investigating in-row plant spacing of 'Charleston Gray' watermelon reported that the narrower the spacing, the higher the total fruit yield and number (Halsey, 1959). Marketable yields of 'Charleston Gray' decreased while yield per plant and fruit weight increased when plant spacing increased from $2 \mathrm{ft}$. $(0.6 \mathrm{~m})$ to $8 \mathrm{ft}$. $(2.4 \mathrm{~m})$ (Brinen et al., 1979). NeSmith (1993) reported that reducing plant spacing in bare ground culture from 7.2 to $3 \mathrm{ft}(2.2 \mathrm{~m}$ to $0.9 \mathrm{~m})$ increased total yield per unit area one out of two years for 'StarBrite' and both years for 'Crimson Sweet' seeded diploid watermelon. The yield increase was primarily a result of the greater numbers of fruit, because average fruit weight responded only slightly to plant spacing. Sanders et al. (1999), reported that in-row spacing affected yield of largefruited, seeded watermelon 'Royal Jubilee' and 'Prince Charles' grown with drip irrigation. Highest marketable yield resulted from using plastic mulch and in-row spacing between $1.5(0.45 \mathrm{~m})$ and $3 \mathrm{ft}(0.9 \mathrm{~m})$ while average fruit weight was lower at these spacings. All of the above studies conducted plant spacing research with large-fruited, seeded watermelon. Little if any research has been conducted on optimum cultural practices with triploid watermelons. This research was undertaken to evaluate the effect of various in-row spacing on the yield of triploid watermelon cultivars using black plastic mulch and drip irrigation.

\section{Materials and methods}

Transplant Production. Seeds of two watermelon cultivars were sown on 16 Apr. 1996, and 11 Mar. 1997 into warmed $\left[85^{\circ} \mathrm{F}\left(29^{\circ} \mathrm{C}\right)\right] 72$-cell $[2$ inches $(5 \mathrm{~cm})$ square, 2.75 inches $(7$ $\mathrm{cm}$ ) deep] polystyrene trays (Speedling Inc., Plant City, Fla.) filled with moistened commercial soilless mix (Metro Mix 350; Scotts Co., Marysville, Ohio). The seeds were sown on a $45^{\circ}$ angle as recommended by Maynard (1989). The trays were then placed in a $90^{\circ} \mathrm{F}\left(32^{\circ} \mathrm{C}\right)$ greenhouse for 1 to $2 \mathrm{~d}$ to germinate the seed. Then, the transplants were moved to a cooler greenhouse set to $80 / 70{ }^{\circ} \mathrm{F}$ day/night $\left(27 / 21{ }^{\circ} \mathrm{C}\right)$, respectively. 'Crimson Jewel,' a 10- to 15-lb (4.5- to $6.8-\mathrm{kg}$ ) red-fleshed triploid cultivar (Sakata Seed America, Inc., Morgan Hill, Calif.), and an 8- to 10-lb (3.6- to $4.5-\mathrm{kg}$ ) yellow-fleshed triploid watermelon, 'Honeyheart' (Petoseed Co., Inc, Saticoy, Calif.), were used. These cultivars were identified previously in research studies as adapted for production in the southern United States (Motsenbocker and Picha, 1996).

Field Production. Field studies were conducted in 1996 and 1997 at the Louisiana State University AgCenter Burden Research Center, in Baton Rouge. The soil used was an Olivier silt loam (Typic Paleudults). In 1996, 1-, 2-, $4^{-}, 6^{-}$, and 8 -ft in-row spacings were evaluated. Based on the results of the first year, the in-row spacings were changed to $2,3,4,5,6,7$, and $8 \mathrm{ft}$ in 1997. Preplant fertilizer $(8 \mathrm{~N}-10.5 \mathrm{P}-$ $19.9 \mathrm{~K})$ was applied before bed making at a rate of $400 \mathrm{lb} /$ acre $\left(448 \mathrm{kgha}^{-1}\right)$ in 1996 and $600 \mathrm{lb} /$ acre $\left(672 \mathrm{kgha}^{-1}\right)$ in 1997 based on soil test recommendations and thoroughly mixed into the row. During bed shaping, black plastic mulch was installed using a commercial mulch layer, and drip irrigation tubing (Turbulent Twin-Wall; Chapin Watermatics, Watertown, N.Y.) was installed in the same operation 4 inches $(10 \mathrm{~cm})$ off center at a 3 -inch $(7-\mathrm{cm})$ depth. Raised beds on 8 - $\mathrm{ft}(2.4-\mathrm{m})$ centers were 18 inches $(46 \mathrm{~cm})$ wide and 8 inches $(20 \mathrm{~cm})$ tall. 
Four-week-old watermelon transplants were hand transplanted into plastic-mulched plots at the various treatment spacings in the field. Ammonium nitrate $(34 \mathrm{~N}-0 \mathrm{P}-0 \mathrm{~K})$ was fertigated weekly for a total of $19.3 \mathrm{lb}$ and $31.8 \mathrm{lb}$ $\left(21.6\right.$ and $\left.35.6 \mathrm{~kg}^{-1} \mathrm{ha}^{-1}\right)$ of $\mathrm{N}$ per acre in 1996 and 1997, respectively. Individual plots consisted of four 30-ft-long (9.1$\mathrm{m})$ rows, the two inner rows for each of the two cultivars each at a randomly selected spacing. The main plots (inrow spacing) were set up in a randomized complete-block design with cultivars (subplot) randomized within each spacing treatment. The two outer rows were planted with 'Crimson Sweet,' an open-pollinated red-fleshed, seeded cultivar, to provide normal pollen for pollination. Both years two beehives were placed at the edge of the field to ensure adequate cross pollination and fruit set. Insect, disease, and weed management practices were conducted in accordance with Louisiana Cooperative Extension Service guidelines (Boudreaux, 1996).
Harvest began on 31 July 1996 and 13 July 1997, with two subsequent harvests 1 week apart each year. At harvest, fruit from each plot were graded as marketable and cull, counted, and the total weight per plot measured. In 1997, each individual marketable fruit was weighed and graded into four weight categories: extra small [ $5 \mathrm{lb}(2.2 \mathrm{~kg})$ to $<8 \mathrm{lb}(3.6 \mathrm{~kg})$ ], small [ 8 to $<14 \mathrm{lb}(6.3$ $\mathrm{kg})]$, medium [ 14 to $<18 \mathrm{lb}(8.0 \mathrm{~kg})]$, and large (>18 lb). Misshapen, rotten and fruit less than $5 \mathrm{lb}$ were considered culls. Four replications of treatments were used each year. Data from each year separately, were subjected to analysis of variance, and orthogonal contrasts were used to analyze trends in results (SAS Institute, 1997).

A cost-return analysis was performed to determine the effect of inrow spacing on the net benefit of triploid watermelon production. Total production costs were estimated from modified watermelon budgets for Louisiana (Hinson and Boudreaux, 2001). Plant- ing and harvesting costs were estimated based on number of plants per acre and yield. The return per acre of triploid watermelon was calculated from the yield data of 1997. Prices for each fruit size category were estimated to be $50 \%$ higher than the average free-on-board (FOB) prices of 'Sangria', a popular seeded cultivar, at the Dallas, Texas shipping point from 1988 to 1997 (USDAAgricultural Marketing Service, 1999). Regression was used to analyze significant trends (SAS Institute, 1997).

\section{Results and discussion}

In-row plant spacing did not influence 'Crimson Jewel' total yield both years (Table 1). Fruit number per acre decreased as in-row spacing increased both years; the highest number of fruit per acre were at the narrowest spacing, $1 \mathrm{ft}$ in 1996 and $2 \mathrm{ft}$ in 1997. Fruit number and fruit weight per plant linearly increased with wider in-row spacing both years; the highest fruit number and weight resulted from the widest spacing and

Table 1. Effect of in-row spacing on 'Crimson Jewel' marketable yield of triploid watermelon in Louisiana, 1996 and 1997.

\begin{tabular}{|c|c|c|c|c|c|c|c|c|c|c|c|}
\hline \multirow{2}{*}{$\begin{array}{l}\text { In-row } \\
\text { spacing } \\
(\mathrm{ft})^{\mathrm{z}} \\
\end{array}$} & \multirow{2}{*}{$\begin{array}{c}\text { Plant } \\
\text { population } \\
\text { (no./acre) }^{\mathrm{z}}\end{array}$} & \multicolumn{2}{|c|}{$\begin{array}{c}\text { Total yield } \\
\text { (tons/acre) }^{\mathrm{z}}\end{array}$} & \multicolumn{2}{|c|}{$\begin{array}{l}\text { Fruit no. } \\
(1000 / \text { acre })^{z}\end{array}$} & \multicolumn{2}{|c|}{$\begin{array}{c}\text { Fruit/plant } \\
\text { (no.) }\end{array}$} & \multicolumn{2}{|c|}{$\begin{array}{c}\text { Fruit wt/plant } \\
(\mathbf{l b})^{\mathrm{z}} \\
\end{array}$} & \multicolumn{2}{|c|}{$\begin{array}{c}\text { Wt/fruit } \\
(\mathbf{l b})^{\mathrm{z}} \\
\end{array}$} \\
\hline & & 1996 & 1997 & 1996 & 1997 & 1996 & 1997 & 1996 & 1997 & 1996 & 1997 \\
\hline 1 & 5,445 & $39.8 a^{y}$ & --- & $7.8 \mathrm{a}$ & --- & $1.4 \mathrm{~d}$ & --- & $14.6 \mathrm{c}$ & --- & $10.2 \mathrm{c}$ & --- \\
\hline 2 & 2,723 & $43.4 \mathrm{a}$ & 31.8 & $7.6 \mathrm{a}$ & $5.5 \mathrm{a}$ & $2.8 \mathrm{~d}$ & $2.1 \mathrm{c}$ & $31.9 \mathrm{c}$ & $23.4 \mathrm{~d}$ & $11.5 \mathrm{bc}$ & $11.6 \mathrm{c}$ \\
\hline 3 & 1,815 & --- & 28.6 & --- & $4.2 \mathrm{ab}$ & --- & $2.3 \mathrm{c}$ & --- & $31.5 \mathrm{~cd}$ & --- & $13.5 \mathrm{~b}$ \\
\hline 4 & 1,361 & $42.4 \mathrm{a}$ & 29.1 & $7.2 \mathrm{ab}$ & $4.0 \mathrm{~b}$ & $5.3 \mathrm{c}$ & $3.0 \mathrm{bc}$ & $62.2 \mathrm{~b}$ & $42.8 \mathrm{bc}$ & $11.8 \mathrm{ab}$ & $14.8 \mathrm{ab}$ \\
\hline 5 & 1,089 & --- & 24.1 & --- & $3.2 \mathrm{bc}$ & --- & $3.0 \mathrm{bc}$ & --- & $44.3 \mathrm{bc}$ & --- & $14.9 \mathrm{ab}$ \\
\hline 6 & 908 & $42.5 \mathrm{a}$ & 19.1 & $6.5 \mathrm{ab}$ & $2.3 \mathrm{c}$ & $7.2 \mathrm{~b}$ & $2.6 \mathrm{c}$ & $93.7 \mathrm{a}$ & $41.9 \mathrm{c}$ & $13.1 \mathrm{a}$ & $16.5 \mathrm{a}$ \\
\hline 7 & 778 & --- & 22.9 & --- & $3.1 \mathrm{bc}$ & --- & $4.0 \mathrm{ab}$ & --- & $58.9 \mathrm{ab}$ & --- & $14.9 \mathrm{ab}$ \\
\hline 8 & 681 & $37.1 \mathrm{a}$ & 24.8 & $5.9 \mathrm{~b}$ & $3.1 \mathrm{bc}$ & $8.6 \mathrm{a}$ & $4.5 \mathrm{a}$ & $109.1 \mathrm{a}$ & $73.0 \mathrm{a}$ & $12.7 \mathrm{ab}$ & $16.3 \mathrm{a}$ \\
\hline Orthogonal contrasts ${ }^{x}$ & & NS & NS & $\mathrm{L}^{* * *}$ & $\mathrm{~L}^{* * *}$ & $\mathrm{~L}^{* * *}$ & $\mathrm{~L}^{* \star *}$ & $\mathrm{~L}^{* * *}$ & $\mathrm{~L}^{* * *}$ & $\mathrm{~L}^{* * *}$ & $\mathrm{~L}^{\star * *} \mathrm{Q}^{\star *}$ \\
\hline
\end{tabular}

${ }^{\mathrm{z}} \mathrm{l} \mathrm{ft}=0.3 \mathrm{~m}, \mathrm{l} .0$ ton/acre $=2.24 \mathrm{tha}^{-1}, 1000$ fruit $/$ acre $=247 \mathrm{l}$ fruit $/ \mathrm{ha}, 1.0 \mathrm{lb}=0.45 \mathrm{~kg}$

${ }^{y}$ Means within a column followed by different letters are significantly different from each other by Duncan's multiple range test, $P=0.05$. Means are an average of four replications.

${ }^{\text {Ns Nonsignificant }} \mathrm{L}=$ linear and $\mathrm{Q}=$ quadratic orthogonal contrasts significant at $99.9 \%(* * *)$ or $99 \%\left({ }^{* *}\right)$ confidence level.

Table 2. Effect of in-row spacing on marketable yield of 'Honeyheart' triploid watermelon in Louisiana, 1996 and 1997.

\begin{tabular}{|c|c|c|c|c|c|c|c|c|c|c|c|}
\hline \multirow{2}{*}{$\begin{array}{l}\text { In-row } \\
\text { spacing } \\
(\mathbf{f t})^{\mathrm{z}} \\
\end{array}$} & \multirow{2}{*}{$\begin{array}{c}\text { Plant } \\
\text { population } \\
\text { (no./acre) }^{z}\end{array}$} & \multicolumn{2}{|c|}{$\begin{array}{l}\text { Total yield } \\
\text { (tons/acre) }^{\mathrm{z}}\end{array}$} & \multicolumn{2}{|c|}{$\begin{array}{l}\text { Fruit no. } \\
(1000 / \text { acre })^{z}\end{array}$} & \multicolumn{2}{|c|}{$\begin{array}{c}\text { Fruit/plant } \\
\text { (no.) }\end{array}$} & \multicolumn{2}{|c|}{$\begin{array}{c}\text { Fruit wt/plant } \\
(1 \mathbf{l b})^{\mathrm{z}}\end{array}$} & \multicolumn{2}{|c|}{$\begin{array}{c}\text { Wt/fruit } \\
(1 \mathbf{l b})^{\mathrm{z}}\end{array}$} \\
\hline & & 1996 & 1997 & 1996 & 1997 & 1996 & 1997 & 1996 & 1997 & 1996 & 1997 \\
\hline 1 & 5,445 & $32.1 \mathrm{ab}^{\mathrm{y}}$ & --. & $8.8 \mathrm{a}$ & --. & $1.6 \mathrm{~b}$ & --. & $11.8 \mathrm{~b}$ & --. & $7.5 \mathrm{~b}$ & --. \\
\hline 2 & 2,723 & $35.8 \mathrm{a}$ & $29.7 \mathrm{ab}$ & $8.3 \mathrm{a}$ & $5.4 \mathrm{a}$ & $3.1 \mathrm{~b}$ & $2.0 \mathrm{c}$ & $26.3 \mathrm{~b}$ & $21.8 \mathrm{c}$ & $8.6 \mathrm{ab}$ & $11.0 \mathrm{~d}$ \\
\hline 3 & 1,815 & --- & $31.2 \mathrm{a}$ & --- & $5.5 \mathrm{a}$ & --- & $3.0 \mathrm{bc}$ & --- & $34.4 \mathrm{bc}$ & --- & $11.3 \mathrm{~cd}$ \\
\hline 6 & 908 & $25.4 \mathrm{bc}$ & $21.4 \mathrm{c}$ & $5.1 \mathrm{~b}$ & $3.1 \mathrm{~b}$ & $5.6 \mathrm{a}$ & $3.4 \mathrm{ab}$ & $56.1 \mathrm{a}$ & $47.2 \mathrm{ab}$ & $9.8 \mathrm{a}$ & $13.9 \mathrm{ab}$ \\
\hline 7 & 778 & --- & $22.0 \mathrm{c}$ & --- & $3.4 \mathrm{~b}$ & --- & $4.3 \mathrm{a}$ & --- & $56.4 \mathrm{a}$ & --- & $13.1 \mathrm{abc}$ \\
\hline 8 & 681 & $21.3 \mathrm{c}$ & $19.3 \mathrm{c}$ & $4.3 \mathrm{~b}$ & $2.6 \mathrm{~b}$ & $6.4 \mathrm{a}$ & $3.9 \mathrm{ab}$ & $62.6 \mathrm{a}$ & $56.8 \mathrm{a}$ & $9.8 \mathrm{a}$ & 14.7 a \\
\hline Orthogonal contrasts ${ }^{x}$ & & $\mathrm{~L}^{* * *}$ & $\mathrm{~L}^{* * *}$ & $\mathrm{~L}^{* * *}$ & $\mathrm{~L}^{* * *}, \mathrm{Q}^{*}$ & $\mathrm{~L}^{* * *}, \mathrm{Q}^{*}$ & $\mathrm{~L}^{* * *}$ & $\mathrm{~L}^{* * *}, \mathrm{Q}^{*}$ & $\mathrm{~L}^{* * *}$ & $\mathrm{~L}^{\star \star}$ & $\mathrm{L}^{* * *}$ \\
\hline
\end{tabular}

${ }^{\mathrm{z}} \mathrm{l} \mathrm{ft}=0.3 \mathrm{~m}, 1.0$ ton/acre $=2.24 \mathrm{tha}^{-1}, 1000$ fruit $/$ acre $=247 \mathrm{l}$ fruit $/ \mathrm{ha}, 1.0 \mathrm{lb}=0.45 \mathrm{~kg}$.

${ }^{\mathrm{y}}$ Means within a column followed by different letters are significantly different from each other by Duncan's multiple range test, $P<0.05$. Means are an average of four replications. ${ }^{\mathrm{x}} \mathrm{L}=$ linear and $\mathrm{Q}=$ quadratic orthogonal contrasts significant at $99.9 \%(* *), 99 \%(* *)$, or $95 \%(*)$ confidence level. 

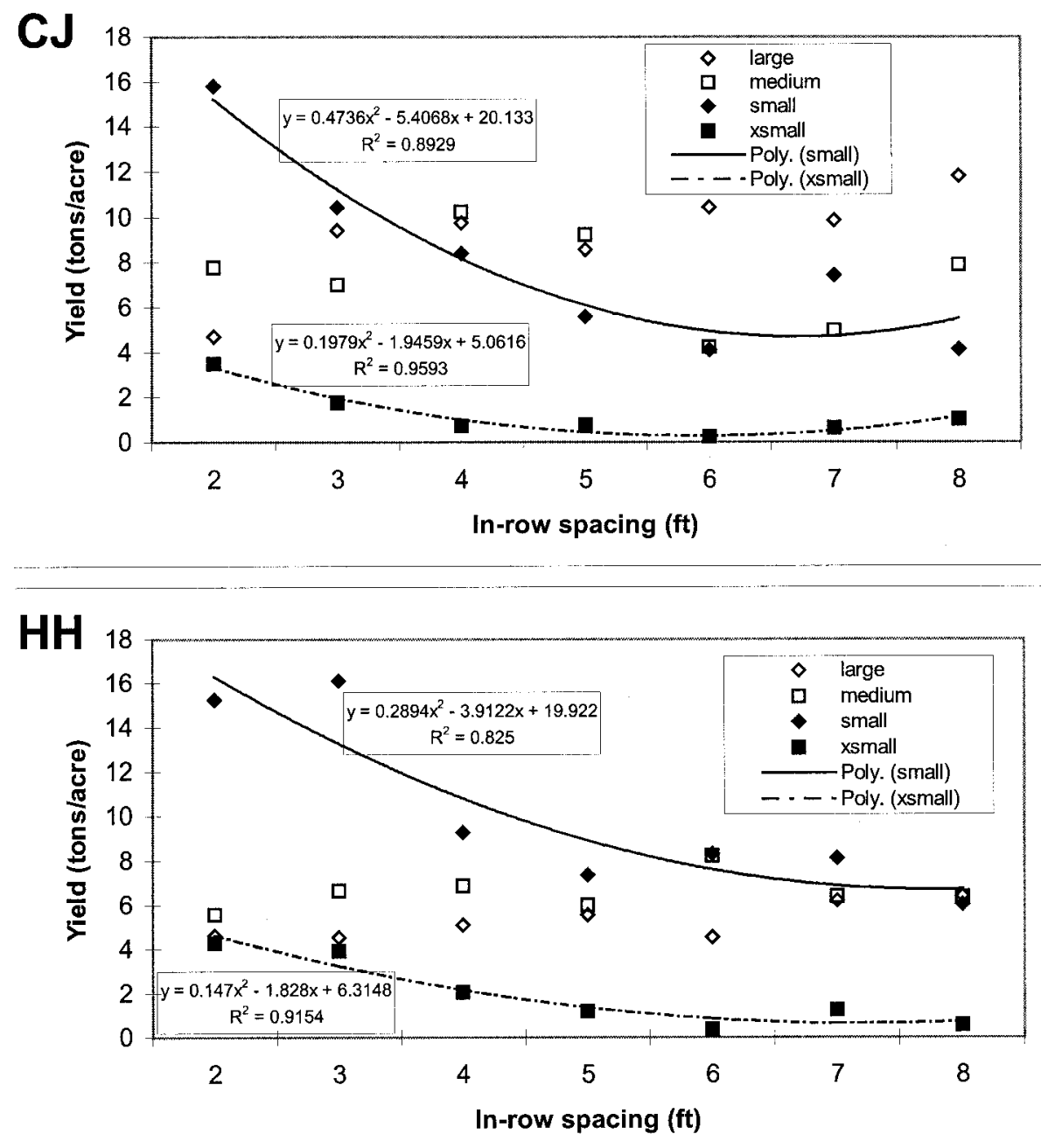

Fig. 1. Effect of in-row spacing on yield (1997) by fruit size category of 'Crimson Jewel' (CJ) and 'Honeyheart' (HH) triploid watermelon. Fruit size categories: xsmall $=\mathbf{5} \mathbf{~ l b}$ $(2.2 \mathrm{~kg})$ to $<8 \mathrm{lb}(3.6 \mathrm{~kg})(\square)$; small = 8 to $<14(6.3 \mathrm{~kg})(\diamond)$; medium = 14 to $<18(8.0$ $\mathrm{kg})(\square)$; large $>18 \mathrm{lb}(\vartheta)$. Regression at $95 \%$ confidence level and correlation $\left(r^{2}\right)$ for each fitting curve. Analysis of variance and regression were not significant for data without the trend line; $1 \mathrm{ft}=0.3 \mathrm{~m}, 1.0 \mathrm{ton} / \mathrm{acre}=2.24 \mathrm{tha}^{-1}$. Poly. $($ small $)=$ polynomial for small fruit and Poly. $($ xsmall $)=$ polynomial for extra-small watermelon fruit.

lowest from the narrowest spacing. Fruit weight was affected by in-row spacing; in 1996 the response was linear and in 1997 the response was quadratic. In general, wider spacings $(6$ and $8 \mathrm{ft})$ resulted in heavier 'Crimson Jewel' fruit.

In-row spacing affected 'Honeyheart' total yield linearly both years (Table 2.). The highest yields were obtained from the closest spacing each year, $4 \mathrm{ft}$ in 1996 and $3 \mathrm{ft}$ in 1997. Fruit number per acre responded in a linear fashion in 1996 and quadratically in 1997; narrower spacing resulted in the highest and the wider spacing the lowest fruit number per acre. Fruit number and weight per plant were affected by in-row spacing; in general, narrower spacing resulted in fewer fruit and lower fruit weight per plant, and wider spacing resulted in higher values. Fruit weight responded lin- early to in-row spacing; wider in-row spacing resulted in heavier fruit both years. There was no difference in cull production due to in-row spacing for either cultivar both years (data not presented).

In 1997, the increase in total yield (tons) per acre for both cultivars at narrower spacing (denser planting) was caused by an increase in extra small and small fruit (Fig. 1). Yields of extra small and small fruit decreased with wider inrow spacing. At the narrowest spacing $(2 \mathrm{ft})$, small fruit were the largest fruit category comprising $54 \%$ of the total yield for both 'Crimson Jewel' and 'Honeyheart'. The next largest fruit category was medium; this category, as well as large-fruit yield, were unaffected by in-row spacing for both cultivars. At the widest spacing $(8 \mathrm{ft})$, large fruit comprised the greatest 'Crimson Jewel' yield category ( $35 \%$ of the total yield) as well as the highest number of fruit per acre $(48 \%)$ while large fruit comprised $24 \%$ of the total 'Honeyheart' yield. The results for fruit number per acre for both cultivars were similar to fruit yield for all four fruit categories (data not shown).

The results of our study indicate that a narrower in-row spacing ( 2 to 4 $\mathrm{ft}$ ) is optimal for maximum yield of the smaller-fruited cultivar 'Honeyheart'. Similar results were reported previously for seeded watermelon (NeSmith, 1993; Sanders et al., 1999). These results also confirm production recommendations from other states. Recommended triploid watermelon spacing in Texas is 12 to $18 \mathrm{ft}^{2}$ ( 1.1 to $1.7 \mathrm{~m}^{2}$ ) per plant; or 2 to $3-\mathrm{ft}$ in-row spacing on $6-\mathrm{ft}$ beds (Daniello, 1996). It was reported that triploid production is successful with 25 to $30 \mathrm{ft}^{2}\left(2.3\right.$ to $\left.2.8 \mathrm{~m}^{2}\right)$ per plant in Florida (Hochmuth et al., 2000).

Our results also indicate that inrow spacing influences primarily extra small and small fruit yields. This is important for practical reasons because watermelon growers can adjust in-row spacing to achieve a particular range in fruit size. It has been reported that the general market for watermelon is tending toward smaller melons, and the ideal size is about 12 to $15 \mathrm{lb}(5.4$ to $6.8 \mathrm{~kg})$ (Blank, 1999). Smaller melons are often preferred for direct sales because they are easier for consumers to transport with little or no assistance from the vendor and the price per fruit (based on weight) is often higher than that for larger-seeded watermelon types. For direct-market growers whooften relyon small melons, i.e., 'Sugar Baby'-size watermelons for sale, a 2- or 3ftin-rowspacing maybeoptimal for smaller melons and high number of fruit per acre. Triploid watermelon growers who sell for the wholesale shipping market and often rely on larger watermelons (>14-lb fruit) should consider wider spacing. Some of the management intensive areas of Texas and Florida that produce watermelons for the wholesale market with shipments out of the growing area use $30 \mathrm{ft}^{2}$ per plant. Our results suggest that wider spacings should be recommended to produce larger watermelons for this particular market. Although large fruit numbers were not different (Fig. 1), the average fruit weight was greater at wider spacings (Tables 1 and 2 ).

Costs per acre were significantly different due to in-row spacing in 1997; with narrower in-row spacing costs increased (Table 3 ). The differences in 
Table 3. Economic analysis of triploid watermelon ('Crimson Jewel' and 'Honeyheart') in-row spacing in Louisiana, 1997.

\begin{tabular}{lccc}
\hline \multirow{2}{*}{$\begin{array}{l}\text { In-row } \\
\text { spacing } \\
\mathbf{( f t}^{\mathbf{x}}\end{array}$} & $\begin{array}{c}\text { Production costs } \\
\text { (\$/acre) }^{\mathbf{x}}\end{array}$ & \multicolumn{2}{c}{$\begin{array}{c}\text { Gross returns }^{\mathbf{y}} \\
\text { (\$/acre) }^{\mathbf{x}}\end{array}$} \\
\cline { 3 - 4 } 2 & $2319 \mathrm{a}^{\mathrm{w}}$ & 4706 & $10252 \mathrm{a}$ \\
3 & $2064 \mathrm{~b}$ & 4815 & $10230 \mathrm{a}$ \\
4 & $1889 \mathrm{c}$ & 4533 & $9529 \mathrm{ab}$ \\
5 & $1738 \mathrm{~d}$ & 3895 & $8051 \mathrm{ab}$ \\
6 & $1662 \mathrm{~d}$ & 3661 & $7449 \mathrm{~b}$ \\
7 & $1656 \mathrm{~d}$ & 3906 & $8032 \mathrm{ab}$ \\
8 & $1625 \mathrm{~d}$ & 3965 & $7827 \mathrm{~b}$ \\
Orthogonal contrasts & $\mathrm{L}^{* * *}$ & $\mathrm{NS}$ & $\mathrm{L}^{*}$ \\
\hline
\end{tabular}

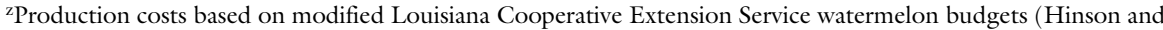
Boudreaux, 2001).

${ }^{y}$ Gross returns for wholesale market based on small, $\$ 7.50 / \mathrm{cwt}(\$ 0.17 / \mathrm{kg})$; medium, $\$ 9.50 / \mathrm{cwt}(\$ 0.21 / \mathrm{kg})$; large, $\$ 9.00 / \mathrm{cwt}(\$ 0.20 / \mathrm{kg})$ and for farmers' market prices of small, $\$ 2.00 /$ fruit; medium, $\$ 3.00 /$ fruit; large $\$ 4.00$ /fruit.

${ }^{\mathrm{x}} \mathrm{l} \mathrm{ft}=0.3 \mathrm{~m}, \$ 1 /$ acre $=\$ 2.47 / \mathrm{ha}$

wMeans within a column followed by different letters are significantly different from each other by Duncan's multiple range test, $P<0.05$. Means are an average of four replications pooled over cultivars..

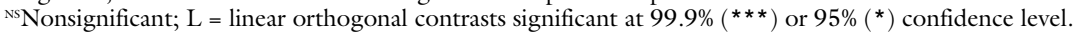

costs among the in-row spacings was primarily due to the cost of seed, transplants, and planting, as well as harvest costs. There is a price advantage to triploid watermelons as it has been reported that consumers were willing to pay more $[50 \%$ or $\$ 0.05 / \mathrm{lb}(\$ 0.11 /$ $\mathrm{kg})$ ] for triploid fruit based on appearance (Marr and Gast, 1991). Wholesale market gross returns based on diploid melon fruit prices received FOB Texas (USDA Agricultural Marketing Service, 1999) with a 50\% increase [small, $\$ 7.50 /$ cwt $(\$ 0.17 / \mathrm{kg})$; medium, $\$ 9.50 / \mathrm{cwt}$ $(\$ 0.21 / \mathrm{kg}) ;$ large, $\$ 9.00 / \mathrm{cwt}(\$ 0.20 /$ $\mathrm{kg})$ ] were not significantly affected by plant spacing. This is in contrast to NeSmith (1993) who indicated that gross returns of seeded watermelon increased with narrower spacing. A local retail farm market sold small ( 8 to $<14$ lb), medium ( 14 to $<18 \mathrm{lb}$ ), and large $(\geq 18 \mathrm{lb})$ watermelons for $\$ 2.00, \$ 3.00$, and $\$ 4.00$ each, respectively. Based on these retail prices for the particular fruit sizes, the gross returns were significantly different as narrower spacings had higher returns. The wholesale market gross returns were lower than the farmers' market returnsindicating a higher return for direct sales of watermelon to consumers, compared to wholesale. The actual price received by growers depends on the particular market forces; growers in our area who have directsales outlets also sell to intermediaries or packing houses on occasion. Net returns (gross returns minus costs), however, were not significantly affected by plant spacing, based on both farmers' market and wholesale prices (data not presented). The economic analysis sug- gests that gross returns increased with narrower in-row spacing only for the higher farmers' market prices.

Growers need to be cognizant of the market demands and adjust their cultural practices accordingly to meet market expectations. Watermelon plant spacing requirements vary depending on the cultivar, the time of planting, soil type, growing area, and environmental influences. In addition, growers need to remember that triploid watermelons are more management intensive. Irrigation, fertilization, pest management practices, and choice of cultivar are important variables that need to be considered when growing triploid watermelons. If a grower bases the decision on in-row spacing only on maximizing yield, then narrower spacing appears to be optimal. The analysis of returns indicates that there is no statistical difference due to spacing for our two cultivars. A grower, therefore, would presumably select the lowest cost in-row spacing while estimating potential returns. Our results indicate that in-row spacing is a variable that can be adjusted by growers to optimize yields and potentially returns. Further research is required to investigate the influence of cultivars and plant population such as the interaction of row configuration and in-row spacing.

\section{Literature cited}

Blank, C. 1999. Watermelon wonder: Seedless varieties are becoming more popular with growers and consumers. The Grower 32(9):16-18.

Boudreaux, J.E. 1996. Commercial vegetable recommendations. La. Coop. Ext. Serv. Publ. 2433.

Brinen, G.H., S.J. Locascio, and G.W. Elmstrom. 1979. Plant and row spacing, mulch, and fertilizer rate effects on watermelon production. J. Amer. Soc. Hort. Sci. 104:724-726.

Daniello, F.J. 1996. Seedless watermelon. Texas commercial vegetable production guide. Texas A\&M Univ., College Station.

Halsey, L.H. 1959. Watermelon spacing and fertilization. Proc. Fla. State Hort. Soc. 72:131135

Hinson, R.A. and J.E. Boudreaux. 2001. Projected costs for selected Louisiana vegetable crops. La. State Univ. AgCenter AEA Info. Ser. 193.

Hochmuth, G.J., D.N. Maynard, C.S. Vavrina, W.M. Stall, T.A. Kucharek, P.A. Stansly, T.G. Taylor, S.A. Smith, and A.G. Smajstrla. 2000. Cucurbit production in Florida, p. 137-156. In: D.N. Maynard and S.M. Olsen (eds.). Vegetable production guide for Florida. Univ. Fla. Coop. Ext. Circ. Sp-170.

Marr, C.W. and K.L.B. Gast. 1991. Reactions by consumers in a farmers' market to prices for seedless watermelon and ratings of eating quality. HortTechnology 1(1):105-106.

Mayberry, K.S., T.K. Hartz, and J. Valencia. 1996. Watermelon production in California. Univ. Calif. Publ. 7213.

Maynard, D.N. 1989. Triploid watermelon seed orientation affects seedcoat adherence on emerged cotyledons. HortScience 24(4):603604

Motsenbocker, C.E. and D.H. Picha. 1996. Quality parameters of triploid watermelons. J. Veg. Prod. 2:3-14.

NeSmith, D.S. 1993. Plant spacing influences watermelon yield and yield components. HortScience 28(9):885-887.

Sanders, D.C., J.D. Cure, and J.R. Schultheis. 1999. Yield response of watermelon to planting density, planting pattern, and polyethylene mulch. HortScience 34(7):1221-1223.

SAS Institute, 1997. SAS for Windows, release 6.12. SAS Inst., Cary, N.C.

The Packer, 1999. Fresh trends: 1999 Profile of fresh produce consumers, Vance Publ., Lincolnshire, Ill.

U.S.Department of Agriculture, Agricultural Marketing Service. 1999. Market news reportsFruit and vegetable. Terminal Mkt. Veg. Rpt. (Dallas, Texas). 7 Dec. 2001. <www.ams.usda. gov/fv/mncs/terminal.htm>

U.S.Department of Agriculture, Economic Research Service. 1998. Table 26-Melons: Per capita consumption, 1970-97. 8 Dec. 2001. <www.ers.usda.gov/data/sdp/view.asp? $\mathrm{f}=$ food $/ 89015 />$. 